\title{
Language and Gender Reconsiliation in Karampuang Ethnic Community of Sinjai District, South Sulawesi
}

\author{
Ery Iswary ${ }^{1}$, Rabina Yunus ${ }^{2}$, Firman Saleh ${ }^{3}$, Fakhira Y Utami ${ }^{4}$ \\ \{1ery.iswary@unhas.ac.id\} \\ ${ }^{1234}$ Faculty of Cultural Studies, Hasanuddin University, Makassar, Indonesia
}

\begin{abstract}
This research will examine the gender symbolism reflected through language in form of utterances quoted from Karampuang legends. This research is qualitative explorative, using several data collection techniques; direct observation, interviews, recording, and gathering documents about the kingdom of Karampuang. The data analysis technique uses the language and gender analysis strategy model (Kramarae). The gender reconciliation referred to in this study is an action or activity that resolves differences through building amicable relation between women and men in the context of Karampuang culture and society. The findings of this study suggest that the symbolization of gender were found in traditional Karampuang traditional houses in which the architectural design and the way spaces are divided within the house, along with the tribal decoration of the house are inspired by the anatomy of the female body. The framework of the house is analogous to the female body in which the Malays refer as the "mother of the house". The element of gender reconciliation through language suggested from the utterances of the female king to the people of Karampuang and to the six male kings she appointed to rule in 6 regions which serve purpose as messages, agreements and agreements. The nobility of women status in the Karampuang community is preserved in the form of traditional Karampuang traditional houses which until now remain perceived as sacred by the local community.
\end{abstract}

Keywords: language, gender, Karampuang, gender symbolism, reconciliation

\section{Introduction}

Language is always present in all dimensions of human life, both in the form of verbal and also non-verbal as in either linguistic or nonlinguistic symbol, it is because nobody is able to construct a meaning to the worldly living without language. Research on language can be studied in various perspectives and assessments, one of those is language and gender studies. According to Katubi (2004) there are 3 reasons why language is currently used as an object of gender studies, firstly language can be an instrument for detecting gender inequality, it is an activity of exploring patriarchal cultural phenomena through the use of language in a culture because language and culture go hand in hand in abstract and concrete forms. The second reason is the realization that the use of language contains clues on how a culture views the world, including gender representation. Another reason is that language influences people in 
behaving and perceiving both women and men in a society or culture. For instance, sexist language will produce unequal situation between women and men.

Language and gender studies according to [1] in his book "Language and gender" juxtapose the difference between folk linguistic and sociolinguistic facts because sociolinguistic facts can experience changes and contradictions from one generation to the next, in tune with the development of the times and their contact with other scientific disciplines. . Research on culture and society using a language and gender approach has been carried out in various regions and even various countries, both focusing on traditional ethnic houses, arts, lifestyle and others.

Previous research on traditional Karampang houses has been carried out by several researchers who generally examine the architectural symbolism of traditional houses only. Research from [2] entitled "Symbolism in Vernacular Karampuang Sinjai Architecture in South Sulawesi" examines the symbolism of the house form in a descriptive manner from an architectural point of view. Other aspects studied are the cosmological system and the process of housing construction and the structural system of two traditional houses with a naturalistic paradigm.

"Gender Culture in a Society from Temporal Ecological and Socio-Economic Perspective" by [3] describes women's active contribution in various fields of economic activity to support the family economy. The women participation in the economy was said to be lackluster due to the social ecology of the community which still preserves discrimination and violence.

According to Mustam, maximizing women empowerment in the socio-economic field requires women to maintain three attitudes, which are their attitudes toward God, to themselves, and to the norms and values that their culture upholds.

Another gender study entitled "Gender in the Minangkabau Community: Theory, Practice, and Scope of Study" by [4] criticizes the kinship system in the Minangkabau ethnic group which emphasizes the issues of women and gender issues, he argues that the group's matrilineal culture is apparently rich of values of gender equality and justice in all of its aspects; from the philosophy, structure and implementation. Men are placed as protectors / guardians dubbed as the "mamak" while women have access to ownership over the properties. Men and women have equal position when it comes to decision-making process in the Minangkabau community.

This study examines the phenomenon of gender symbolization found in Karampuang indigenous people's cultural icon, that is a traditional house. The layout of the house is made by taking ideas from the anatomy of the female body, hence it is intuitive to analyse it from the aspect of gender symbolization; not to mention it is also compelling to pay attention at the traditional Karampuang tribe leaders of the past and present managing to do gender reconciliation. Historical records containing the expressions and statements of the first King (female) toward her people and the King's relationship with other 6 male kings she rules over are potentially rich of discussion and necessary to be explored further as an indication of the reconciliation of female and male leaders. Based on this phenomenon, the problem to be discussed in this working paper is how the gender symbols found in the architecture of the Karampuang traditional house and how the form of gender reconciliation is reflected through language in the form of statements in the historical story of the Karampuang community. The purpose of this study is to explore the gender symbols found in the traditional architecture forms of the Karampuang traditional house and to reveal the forms of gender reconciliation that are reflected through language in the historical records of the Karampuang community. 
Gender can be interpreted as roles and responsibilities that are socially conceptualized given to female and male in a particular society or culture supported by the relevant community structure. The concept of gender according to Fakih in [4] explained that a trait inherent in female and male socially and culturally constructed. Gender differences can be socially constructed and strengthened through the force of institutions such as culture, religion, and the state. Bourdieu's paper stress on early famililiarization for the highest value of cultural capital is closely linked to his idea, strongly emphasized in Distinction, about the role of family and domestic life for individual development and social positions. The role of women, as mothers and homemakers, is crucial in this process [5] The more important the female partner was in influencing the decision to stay home, the lower the levels of masculine characteristics and the more enjoyment men reported in being a stay at home father [6].

Gender equality is not just about economic empowerment. It is a moral imperative. It is about fairness and equity and inclused many political, social and cultural dimensions. [7]. Despite early claims that women are naturally more conserving of resources, the empirical literature, in particular, gives a more mixed and nuanced picture. Conservation is influenced not only by gender but also by a host of tangible and intangible factors, including local ecology, context, and culture, that affect incentives and the ability to adopt sustainable extraction and provision [8]

Kramarae's in [9] describes the models of language analysis in language and gender studies which currently attract the attention of language researchers in various contexts. There are 4 Kramarae version analysis models, namely (1) the mute group model that provides a way to visualize and conceptualize hidden structures (such as the Chomsky version of the deep structure) and realized structures, namely articulations of world view; (2) psychoanalytic model (3) Speech design models that can be used to explain the language behavior of women and men as dominant or subordinate group members. (4) Strategic models state that social speech always has a context and can describe the position of women in society that can be ideologically and spatially separated and can indicate gender power relations.

The strategic model framework applied in this study because it is considered more relevant to express gender symbolization and forms of reconciliation in the Karampuang community. Traditional houses usually express cosmological symbols, contain beliefs and relationships between humans and God, humans and the harmony of nature, as well as beliefs that have philosophical value in their communities Kustedja in [9] Salzmann provides good and terse summaries of gendered elements in language and gender discursive types and also briefly discusses the sociolinguistic concept of the "social network" which is methaphorically (if not literally) remediated in fecebook [10] Gender Equality and Development argues that gender equality is a core development objective in its own right. It is also smart economics. Greater gender equality can enhance productivity, improve development outcomes for the next generation, and make institutions more representative[11]. The large literature on gender and mobility, teasing out what I see as two disparate strands of thinking that have remained badly disconnected from each other. One of these strands has informed understandings of how mobility shapes gender, while the other has examined how gender shapes mobility. [12] 


\section{Research Method}

This research takes place in the village of Bulupoddo Karampuang, Sinjai district. This research is qualitative exploratory. Data collection techniques are carried out using direct observation techniques in the field to observe the architectural forms of traditional houses that adopt the anatomical forms of women's bodies. Interview techniques are also conducted with informants named Arung / to matoa (the current King of Karampuang), sanro, gella and Karampuang cultural activist. Recording techniques and documentation techniques are also performed to produce records to revisit later.

The data analysis technique follows these stages e.g.data obtained from the results of observations are classified in detail based on the symbols found ; interpreting and signifying every symbol found based on observations and interviews; analyzing verbal statements that express gender reconciliation.

Gender reconciliation in the context of this study is the act or activity of resolving differences in the form of friendly relations between men and women in the cultural context of Karampuang. The form of gender reconciliation that is explored is related to the reconciliation of the roles of women and men in carrying out daily activities and activities in carrying out traditions that are still maintained by the Karampuang community. This gender role will be classified based on aspects of authority, aspects of the division of labor and cultural allocation of power.

\section{Results And Discussion}

The traditional house of Karampuang's design reflects the anatomy of a woman's body as one of the tribute to the first King in Karampuang who was a woman. The symbols oriented towards the anatomy of a woman's body can be described from head to toes [13].

The aspect of women's authority indicates that the Karampuang region in the past played an important role because it held the highest position as the leader of the people and appointed 6 men as regional rulers in each area. The social value and power authority that generally places men in the undisputable higher social classes does not apply in the Karampuang custom. Another aspect of authority is emphasized when female king issued a decree stating that the six men she trusted were assigned to rule in their respective territories, and must continue to protect the Karampuang region by any means despite their new convenient status as King. The violation of this pledge will result the power of the male kings being forcefully taken back by the female king and they would lose their authority as the consequence.

The statement found in the Karampuang historical record documents suggests that in ancient times women were dominant in the leadership aspect because the first king of Karampuang was a woman who suddenly appeared from the sea, standing in the middle of coconut shell-looking basin that protrudes from the sea

\section{"eloka tuo tea mate, eloka madeceng tea maja" \\ "I desire to live not die, I desire goodness not anything hideous'}

This expression was spoken by To Manurung, a woman, in front of Karampuang people in her first appearance from the sea. This expression is a will the people must inherit to keep guarding customs and traditions of Karampuang. After that, it is said that she disappeared yet 
in the not-too distant future To Manurung reappeared along with six men whom she would plot as kings in 6 regions. Before their departure to the respective region, she advised :

"Nonno'no makkale lembang, numaloppo kualinrungi, numatanre kuaccingungi, makkelo kuakkelori, ualai lisu"

'You shall leave to rule elsewhere yet the dignity of your throne belongs to mine as in my other possessions for the sake of protecting Karampuang. You are entitled of the honor you earned, use it to honor your ancestors as well. However, your will is only true if it is also my will, otherwise your power will be invalidated."

The leadership of women was indicated as dominant when the Karampuang region was led by the female King who even had the authority to control the other male rulers. The division of labor and the allocation of power among the cultural figures is distributed in accordance with the customary positions held by each where Arung as the highest leader of his work lays hands on afterlife-related affair and other important decision-making, sanro performs duties of social administration and religious affair, Guru plays the role as the minister of education, and Puang Gella is prime minister.

\section{Conclusion}

The fundamental philosophy and tradition that has been passed down by the female king remains preserved. Gender reconciliation is maintained where women and men continue to respect each other and carry out their respective roles and in their respective work authorities.

Gender symbolization found in the architectural form of Karampuang traditional ethnic house is meant to show the highest honorable tribute to the first King who happens to be a female and serves as the foundation ground for the customs and traditions which remain preserved up to now are built upon. The house form is analogous to female body anatomy as an intention to hope for productivity and fertility which are associated mainly to women as a maternal figure.

\section{References}

[1] J. Coates, Women, men and everyday talk. 2013.

[2] A. M. and R. W. Radja, "Simbolisme dalam Arsitektur Vernakuler Karampuang-Sinjai Sulawesi Selatan," in Prosiding temu ilmiah IPLBI, 2016.

[3] A. Mustam, "Budaya Gender dalam Masyarakat Perspektif Temporal Ekologi dan Sosial Ekonomi,” J. Al-Maiyyah, vol. Vol.10, no. No. 1, pp. 186-209, 2017.

[4] S. Fatimah, "Gender dalam Komunitas Masyarakat Minangkabau: Teori, Praktek, dan Ruang Lingkup kajian,” J. Ilm. Kaji. Gend., vol. 2, no. 1, pp. 11-24, 2015.

[5] E. Silva, "Gender, homr and family in cultural capital theory," Br. J. Sociol., 2005.

[6] J. Fischer. V. Anderson, "Gender role attitudes and characteristics of stay at home and employed fathers," Psychol. Men Masculinity, 2012.

[7] S.-G. of the OECD, Closing the gender: Act now. OECD, 2012.

[8] A. Q. R. Mainzen-Dick, C. Kovarik, "Gender and Sustainability," Annu. Rev. Environ. Resourches, 2014.

[9] Katubi, "Studi Bahasa dan Jender: Sejarah Singkat, Ancangan, dan Model Analisis," J. Masy. dan Budaya, vol. VI, no. 1, pp. 37-55, 2004.

[10] J. Stanlaw, N. Adachi, and Z. Salzmann, Language, Culture, and Society. New York: Routledge, 2018.

[11] W. Bank, Gender Equality and Development. Washington, DC, 2012. 
[12] S.Hanson, "Gender and Mobility: New approaches for informing sustainability," 2010.

[13] K. Saddhono, "Language of Coastal Communities in the Northern Coast of Central Java: Sociolinguistic Studies in Cultural Integration Maritime-Agrarian Perspective." Adv. Sci. Let. vol. 23 no. 10 pp 10054-10056, 2017 